\title{
Revista Española de Antropología Americana
}

ISSN: 0556-6533

https://dx.doi.org/10.5209/reaa.72881

\section{Indios de Cuba y etnólogos cubanos}

\author{
Eduard Aleksandrenkov ${ }^{1}$
}

Recibido: 21 de noviembre de 2020 / Aceptado: 5 de julio de 2021

Resumen. Los aborígenes de Cuba ("indios") sufrieron pérdidas demográficas irreparables con la conquista y colonización de la isla por los españoles. Además, ya en el siglo XVII acabaron, según escritos contemporáneos, "mezclados". Su mayor concentración fue en varios "pueblos de indios", el último de los cuales, El Caney, se mantuvo hasta mitad del siglo XIX. Ya para fines del siglo XVIII se manifestó la tendencia por parte del poder colonial de la isla de ignorar a sus pocos "indios", mientras que sólo eran reconocidos como tales en sus lugares de habitat. Aunque los etnólogos cubanos nunca mostraron interés por estos "indios", los antropólogos físicos de varios paises, incluidos cubanos, sí hicieron acto de presencia en algunas partes del Oriente de la isla. No obstante, esta presencia fue opacada por la importancia en lo económico, lo cultural y lo social del componente afrocubano de la población. Precisamente en el estudio de esta parte de la sociedad cubana se levantó el cuerpo de la etnología cubana, gracias a la obra de Fernando Ortíz. Otro factor a tener en cuenta es la inestabilidad institucional de la etnología en Cuba, a lo que hay que añadir la quietud social de los mismos "indios", por lo menos, hasta hace poco tiempo.

Palabras claves: indios; pueblos de indios; etnólogos cubanos.

\section{[en] "Indians" of Cuba and Cuban Ethnologists}

\begin{abstract}
The natives of Cuba ("Indians") suffered irreversible losses in population during the Spanish conquest and colonization. Besides, already in the XVIIth century they became "mixed", as described by the contemporaries. Their major concentration was in several "pueblos de indios", the last of which El Caney existed till the mid XIXth century. By the end of the XVIIIth century, the central authorities tended to ignore the existence of the few "Indians" although the latter were still considered as such in the areas of their living. The Cuban ethnologists did not perceive their "Indians" although the physical anthropologists from different countries, including the Cuban ones, demonstrated existence of those in several places in the East of the island. The cause of this can be attributed to several factors. The first one is that existence of descendants of the Cuban natives was marginalized by the importance of the Afro-Cuban component of the population in the economy, culture and society. The study of this very group formed the body of the Cuban ethnology, thanks to works of Fernando Ortiz. Another factor was the institutional instability of the ethnology in Cuba. The possible third one, the social quietness of themselves "Indians", at least until recently.
\end{abstract}

Keywords: Indians; pueblos de indios; cuban ethnologists.

Sumario: 1. Preliminares. 2. Primera mitad del siglo XVI (la catástrofe). 3. De las Leyes Nuevas a los primeros censos generales (supervivencias). 4. Desaparición de los focos de aborígenes oficialmente reconocidos. 5. Antihispanismo y aborígenes. 6. Segunda mitad del siglo XIX (la antropología naciente y los aborígenes). 7. Primera mitad del siglo XX (el creciente interés por el pasado aborigen). 8. Después

Instituto de Etnología y Antropología de la Academia Rusa de Ciencias, Departamento de América. ed_alex@mail.ru. 
de 1959 (negados por el estado e ignorados por los etnólogos cubanos). 9. Revitalización "taina" e indios cubanos. 10. Conclusiones. 11. Referencias.

Como citar: Aleksandrenkov, Eduard. 2022. "Indios de Cuba y etnólogos cubanos”. Revista Española de Antropología Americana 52 (1): 81-94.

\section{Preliminares}

El estudio de los aborígenes fue uno de los hitos principales de la formación de la etnología en varios países de América. En la mayoría de los países antillanos no han llegado hasta el presente los descendientes directos de la población preeuropea, con excepción de Cuba donde en el extremo oriental de la isla sobrevivieron grupos e individuos que se consideran indios pero que, sin embargo, no fueron estudiados por los etnólogos locales. Una aclaración de las causas de este hecho podrá ser útil para la comprensión de las circunstancias que influyen en la selección de los temas a investigar.

\section{Primera mitad del siglo XVI (la catástrofe)}

La ocupación de Cuba por los españoles empezó con la llegada de una expedición encabezada por Diego de Velázquez a finales del año 1510. La cantidad estimada de aborígenes que habitaban la isla a inicios del siglo XVI varió según el método de cálculo empleado por los investigadores. El demógrafo cubano J. Pérez de la Riva (1972) la calculó en más de 110.000 personas, siendo la parte oriental de la isla la más densamente poblada.

Siguiendo la práctica establecida en La Española, Velázquez, a medida que ocupaba nuevos territorios, repartía a sus habitantes entre los conquistadores, por medio de las encomiendas. Entre estos y los aborígenes se impusieron unas relaciones de vencedores y vencidos, dueños y subyugados, y cualquier intento de protesta de los aborígenes se reprimía sin contemplaciones. La vida de los encomendados debía adecuarse a las ordenanzas de las Leyes de Burgos de 1512 (con adiciones de 1513) que reglamentaban todas las esferas de su existencia: vivienda, comida, trabajo, religión, familia (Konetzke 1953: 38-57). Las Leyes, sin embargo, no frenaron la constante disminución de la población aborigen. Entre las causas del rápido descenso de la población nativa en Cuba los demógrafos indicaban el hambre, el excesivo trabajo, las epidemias, el desplazamiento a otras tierras con los españoles, etc. (Pérez de la Riva 1972: 78-83).

En 1542 fueron promulgadas las llamadas Leyes Nuevas, destinadas a todas las colonias españolas del Nuevo Mundo. Pero se dedicó a los aborígenes de tres islas antillanas un acápite aparte:

“... Mandamos que los indios que al presente son vivos en las islas de San Juan y Cuba y la Española, por agora y el tiempo que fuere nuestra voluntad no sean molestados con tributos ni otros servicios reales ni personales ni mixtos más de como lo son españoles que en las dichas islas residen y se dejen holgar, para que mejor puedan multiplicar y ser instruidos en las cosas de nuestra santa fe católica, para lo cual se les den personas religiosas cuales convenga para tal efecto" (Konetzke 1953: 220). 
De esa manera la Corona española reconocía que los aborígenes de estas islas habían perdido la importancia económica que antes habían tenido para ella.

\section{De Leyes Nuevas a los primeros censos generales (supervivencias)}

Después de varios intentos las Leyes Nuevas fueron definidamente aplicadas en 1552 en la Habana y, en 1553, en Santiago, Bayamo y otras villas, cuando "fueron declarados e pronunciados por personas libres muchos yndios, asy honbres como mugeres, y fueron puestos en su libertad" aquellos esclavos, dueños de los cuales no tenían títulos correspodientes (CDI-2 1891, t. 6: 356-357). Según el geógrafo e historiador cubano Leví Marrero, a mediados del siglo XVI habitaban en Cuba cerca de 220 vecinos españoles, 1000 indios y 700 negros esclavos (Marrero 1972, t. 1: 158). Los cálculos del demógrafo cubano Pérez de la Riva eran diferentes: 1800 indios locales y 200 traidos desde fuera. Además, como supuso el demógrafo, podían existir varios miles de fugitivos (Pérez de la Riva 1972: 77-78).

En las Leyes Nuevas no se decía nada sobre la relación de los aborígenes con la tierra. Posteriormente se editaron unas cuantas provisiones donde se indicaba la necesidad de hacer "pueblos de indios" señalándoles los "términos en que pudiesen sembrar los frutos necesarios y criar los ganados que tuviesen" (Konetzke 1953: 284). En el occidente de Cuba, no lejos de la Habana, había un pueblo de indios, Guanabacoa, oficialmente constituido como tal en 1554. No tenía ayuntamiento, y sus asuntos los atendía el cabildo de La Habana (Azcárate 1937: 238-239; Arrate 1964: 38, 103). Otros vecinos indios residían en la propia La Habana. En el verano de 1555 los indios de La Habana y Guanabacoa pelearon contra el pirata francés Jacques de Sores (CDI-2 1891, t. 6: 365-372).

En la parte central de la isla, en Sancti Spiritus, una de las antiguas villas españolas, a fines de los años 1550 residían 6 o 7 vecinos españoles y otros tantos indios, todos "muy pobres", según el documento (Zerquera 1977: 83). En otra villa de la misma región, Trinidad, en aquellos años no había ningun vecino español. Los habitantes de ambas villas monteaban ganado, vendían los cueros y compraban vestidos. Sobre la vida de los de Trinidad se puede juzgar por su apelación al gobernador en mayo de 1562. Según ellos, tenían sus estancias, labranzas, así como corrales de puercos, caballos y vacas. Pedían que se les enviara un clérigo o se les permitiera que ocupara este cargo uno de ellos que lo había oficiado durante muchos años. Se quejaban de que los españoles de Sancti Spiritus les hicieran servirles como si fuesen esclavos (Zerquera 1977: 88-89). Por el documento se ve que los indios de Trinidad se consideraban parte de la sociedad colonial, en cuanto vecinos de una villa preocupados por el destino de toda la isla.

En provincias orientales como Camaguey y Oriente, según Marrero (1974, t. 2: $77,352-353$ ) existían también pueblos de indios. No todos los aborígenes liberados se convertirían en los vecinos de tal o cual villa española o pueblo de indios ya que, sin tener la tierra donde asentarse, se verían obligados a "vagar", como más de una vez mencionan los documentos de la época.

En la relación del obispo Juan de Castillo, sobre la visita hecha en 1569-1570, como pueblos de indios figuraban Los Caneyes -cerca de Santiago- con 20 indios y Guanabacoa con 60 indios casados. Villa Trinidad seguía sin españoles, con 50 indios casados. En las poblaciones españolas de Sabana y Sancti Spiritus había tantos 
vecinos indios como españoles (10 y 20 respectivamente). Los indios superaban a los españoles en las villas de Baracoa (17 y 8), Bayamo (80 y 70) y Puerto Principe (40 y 24). El obispo no mencionó a los indios ni en Santiago, ni en La Habana pero sí a los 32 vecinos españoles en el primer lugar y a los más de 60 en el segundo (Papeles 1931, t. I: 217-225). Según un apéndice anónimo a esta relación en la isla no había ningún indio y la mayoría de la población era mestiza o negra (Papeles 1931, t. I: 226). Es decir, para algunos españoles la diferenciación de indios y mestizos dejó de ser sustancial. Esta tendencia ya se evidenció en la descripción de los hechos relacionados con la defensa de La Habana en 1555, cuando la misma gente unas veces se calificaba como "indios" y otras como "mestizos" (CDI-2, t. 6: 365-370, 390, 391, 402, 409, 415-417).

En la vida cotidiana los indios de Cuba ya no presentaban ningún problema de importancia para las autoridades, lo que se ve claramente en las Ordenanzas, elaboradas en 1574 para La Habana y validas para el resto de la isla. La palabra "indios" se mencionó en cuatro $(17,18,47,79)$ de sus 88 artículos. Sólo la ordenanza 47 estuvo orientada directamente a ellos'. Bajo el pretexto que "los indios beben el vino muy desordenadamente y por experiencia se ha visto que mientras lo tienen no trabajan, ni entienden en cosa alguna y de ello suceden otros muchos inconvinientes" se prohibía "vender vino en el pueblo de los indios, ni Guanabacoa ni en otra taverna, ni llevarlo en botijas para lo vender". Como se dijo en el documento, "si algún indio tuviere necesidad de beber vino por alguna razón", la licencia corresponiente podía ser dada por el protector de los indios, gobernador o alcalde (Ordenanzas 1905).

Pero en casos de urgencia las autoridades apelaban a la ayuda de indios. En febrero de 1582, en vista de la amenaza de un ataque pirata, el gobernador de Cuba envió a "toda la isla" la orden de estar preparados y de remitirle la lista de hombres aptos para acciones militares en cada población, tanto españoles, como mestizos, mulatos e indios. En Guanabacoa donde, según palabras del gobernador, había "yndios y mulatos y mestizos buenos mozos" hizo una compañía de 50 de ellos. El gobernador pasó también revista a los indios, mestizos, mulatos y negros horros ${ }^{3}$ de La Habana (Papeles 1931 t. II: 93). Frente a la opinión del gobernador, el alcalde de la fortaleza de La Habana llamó a los indios de ambas poblaciones "hombres inútiles y mayores de edad" (Papeles 1931, t. II: 182-185). Sin embargo, cuando más tarde en colonias americanas de España se instituyeron las milicias, en algunas partes de Cuba se formaron también compañías de indios a la par que las de españoles, negros horros y mulatos libres.

A principios del siglo XVII surge una nueva caracterización de aborígenes de Cuba. Según el obispo Juan de Cabezas Altamirano (carta de 1608 al rey) Guanabacoa y Baracoa no podían ser llamados pueblos de indios, porque estaban "españolados". La mayoría de los que vivían en Puerto Principe, Bayamo y Santiago de Cuba, formando "como arrabal de estos pueblos", estaban mezclados y "ya como españolados" (en Marrero 1976, t. 3: 14-15, 20).

Los nativos seguían perdiéndose en otras capas de la población y así, según la relación del obispo Alonso Enríquez de Armendáriz de 1620, en Santiago con un total de 250 "almas" no había más de una docena de indios. Estaban "ya mezclados y connaturalizados con los españoles y la tierra”. En Bayamo había cerca de 1500 per-

Como comparación: fue destinado a "negros" un bloque de 14 ordenanzas.

Horros: dicho de una persona que, habiendo sido esclava, alcanza la libertad (RAE). 
sonas, "así de españoles como de indios, negros y mulatos" y "todos mezclados". En Puerto Príncipe entre unas 300 personas había "media docena de indios". En SanctiSpiritus los indios eran 6 o 7 de un total de 200. En villa del Cayo no se mencionaba indios, antes siempre presentes en este lugar. En Trinidad, escribía el obispo, la mayoría de las 150 almas eran "descendientes de indios y mulatos". En Guanabacoa la mayoría de sus 170 personas eran calificadas como "descendientes de indios", y vivían allí también "algunos españoles mezclados”. En La Habana, con una población total de cerca de 7.000 personas, el obispo no mencionaba a indios, ni tampoco en su relato de Baracoa (Documentos 1973: 567-569). Contestando a la demanda real de comunicar sobre el tratamiento de los indios, el obispo escribió: "supuesto, que no hay indios en esta isla, que sean verdaderos indios, sino los pocos que he referido se hallan en cada pueblo mezclados ya con los españoles. Estos son de misma suerte tratados y enseñados como los demás españoles" (Documentos 1973: 574).

En 1618 la Corona española firmó varias leyes que definitivamente debían suprimir las formas aborígenes de gobierno que se conservaban parcialmente en algunas partes de las colonias españolas. La estructura de la administración en las poblaciones nuevas seguía la de los municipios españoles (Recopilación 1841, Libro 6, título 3, leyes VIII, XV, XVI). Precisamente en este año en el oriente de Cuba fue oficializado un pueblo de indios con el nombre de San Luis de los Caneyes, con su cabildo (Reyes 2009: 8-9). Los habitantes de Los Caneyes (en algunos casos, El Caney) padecían continuamente la presión por parte de los vecinos de Santiago de Cuba, que se apropiaban de sus tierras y, por esta causa, varios vecinos dejaron su pueblo (Marrero 1976, t. 3: 225). Con el fin de concentrar a los diseminados, a principios del siglo XVIII fue hecho otro pueblo de indios, Jiguaní (Licea 2012).

De acuerdo con el obispo Pedro Agustín Morell de Santa Cruz, quien hizo su visita por la isla en los años 1754-1757, en Jiguaní había un total de 588 habitantes. Según expresión del obispo, quedaba poco de “color de esta nación", la mayoría eran mestizos con algunos blancos. En El Caney vivían más de 500 personas la mayoría, según el obispo, mestizos. Sobre Guanabacoa Morell escribió: "en lo antiguo era pueblo de indios: extinguiéronse con el tiempo y subrrogaronse otras gentes de distintos colores" (Morell 1985: 39, 108, 114-115). Opinión parecida la expresó el contemporaneo de Morell, Nicolás J. de Ribera: "Solo se han quedado... los pocos indios que havitan en San Luís de los Canelles y Jiguaní". A pesar de que cada una de estas poblaciones tenía una compañia de milicias de indios, un juicio de Ribera ayuda a comprender la actitud posterior de las autoridades hacia los descendientes de los aborígenes: “[...] puede dividirse la gente de la Ysla, por su color en tres clases. En blancos, mulatos y negros" (Ribera 1975: 100-101, 122).

Para los observadores y autores externos, como eran Morell y Ribera, los habitantes de San Luis de los Caneyes y Jiguaní ya eran mestizos, mientras en las propias poblaciones muchos de ellos seguían considerándose "indios". La idea de que en Cuba no había indios se oficializó de una manera determinante durante la realización y publicación de los primeros padrones nacionales de población, iniciados en los años 1770. Las listas de pobladores fueron hechas por curas y administradores locales, separadamente para cada pueblo y su partido. Según tales padrones en el año de 1775 en el pueblo San Luis del Caney la mayoría de los pobladores adultos y niños fue categorizada como "indios", 528 de 570, el resto eran "blancos" (21 personas), "mulatos libres" (18), "negro libre" (1) y "negro esclavo" (2) (Padrón [...] del pueblo de San Luis del Caney 1775). La composición del partido era diferente: 
237 "indios", 203 "negros esclavos", 90 "negros libres", 74 "blancos", 40 "mulatos libres", 1 "mulato esclavo" (Padrón [...] del partido del Caney 1775). En el pueblo de Jiguaní se fijaron 779 "indios", 35 "mulatos libres", 24 "negros esclavos" y 2 "blancos" (Padrón [...] del pueblo de Jiguaní 1774) y en su partido - 463 "indios" (o "naturales") y 2 "negros esclavos" (Padrón [...] de la jurisdicción de Jiguaní 1774)4.

Son evidentes las diferencias en las denominaciónes de la mayoría de los habitantes de los pueblos en cuestión entre las presentadas por Morell ("mestizos") y por los que llenaron las listas del censo ("indios").

Se conocen dos relaciones compuestas a base de los padrones de los años 1770: una lista abreviada y otra más amplia firmada por el gobernador. Una relación más fue hecha por el obispo a partir de las comunicaciones eparquiales. Las relaciones del gobernador y del obispo contienen los datos de San Luis de los Caneyes y Jiguaní. En ninguna de ellas hay rúbrica de "indios" (Pérez de la Riva 1977: 7-8). Al comparar las cantidades de pobladores del padrón de 1775 y las de las relaciones posteriores, queda evidente que las personas catalogadas en el padrón de 1775 como "indios" lo mas seguro es que estuvieran en las categorías de "blancos" y "mulatos libres" en las relaciones mas tardías.

En estos años la población total de Cuba era de algo más de 170.000 personas, y unos cuantos centenares de indios carecían de importancia e interés para los gobernantes de la isla. Cuando los resultados de los censos fueron publicados -en Españaen ellos ya no había rúbrica de "indios".

Desde medianos del siglo XVIII se llevaban a Cuba aborígenes del norte del virreinato de Nueva España que habían sido vendidos como castigo por su rebeldía contra los españoles. Algunos de ellos se fugaron y sembraron el pánico entre los habitantes de diferentes partes de la isla. Genericamente se los denominó "guachinangos". En la defensa de La Habana contra los ingleses en 1762 estos participaron en las acciones militares (Santamaría y Vázquez 2013: 18-32). A Cuba llegaron también más de un centenar de indios de La Florida, quienes tomaron partido por España en el conflicto hispano-inglés, que fueron bautizados y puestos a residir en Guanabacoa (Santamaría y Vázquez 2013: 14-15).

\section{Desaparición de los focos de aborígenes reconocidos oficialmente}

E1 11 de enero de 1821 una orden real igualó a los indios con los españoles, afirmando que salieron del estado de niñez en el cual se encontraban según las antiguas leyes. Las tierras comunales tenían que pasar a la disposicón de la Corona (en Pichardo 1945: 22). Unos años más tarde, supuestamente en junio de 1837, Jiguaní dejó de ser pueblo de indios, para recibir el rango de villa (Licea 2012).

En 1839 en La Habana tuvo lugar un hecho curioso. Durante los festejos por la institución de la Real Audiencia Pretorial, la comparsa que presentaba diversas provincias de España participó en uno de los bailes de máscaras. Entre aragoneses, asturianos y otros, había indios que representaban a Cuba, y su jefe habló en una lengua indígena. El historiador cubano Antonio Bachiller supuso que esta lengua podía ser el maya y, según su conocimiento, el discurso pronunciado por uno de los indios

4 En 1775 también fueron registrados “indios” en Holguín, 139 personas (Valcarcel 2015). 
participantes fue publicado tan solo en español. En aquel texto se decía: "paz, unión $\mathrm{y}$ fraternidad ha sido nuestra divisa y con ella hemos sabido adquirir la opulencia y esplendor que disfrutamos" (Bachiller 1883: 9, 394-395).

La realidad fue otra y, cuando en 1845 la Audiencia Real tomó la decisión de que volvieran las tierras de El Caney a la Corona, los habitantes de El Caney iniciaron un pleito para defender sus intereses. En 1849, tras las protestas del cabildo de El Caney, los que pudieron comprobar que eran indios puros obtuvieron las tierras (Pichardo 1945: 22-23). Son interesantes las pruebas planteadas por el síndico del cabildo de que una persona fuera indio: genealogías constatadas en los libros eparquiales y aparencia de la persona ("los colores bronceados, el pelo negro y lacio y los demás tipos que describen al indio") (en Rivero de la Calle 1978: 155-156). Nada se dice del idioma o de elementos de cultura material.

Las tierras que recibieron los indios de El Caney ya no eran comunales ni estaban protegidas por una legislación especial. La presión de los terratenientes vecinos favoreció la salida de indios a otros lugares menos accesibles (Rivero de la Calle 1978: 157-158).

\section{Antihispanismo y aborígenes}

Cuando en las colonias antillanas de España crecieron los sentimientos independentistas, los indios del pasado empezaron a ser imaginados por los patriotas como protagonistas de las luchas por la libertad. En Cuba a mediados del siglo XIX los temas indios tuvieron un fuerte desarrollo dentro de la poesía. José Fornaris publicó en 1855 Cantos de Ciboney, que fueron reeditados en varias ocasiones. La corriente poética surgida, el "siboneismo", elogiaba a los indios idealizados de Cuba bajo el nombre de "siboneyes" (Azcárate 1937: 248-252). Pero, a pesar de ello, las necesidades de los indios de El Caney y sus luchas por la tierra no encontraron mención alguna en la opinión pública.

En cuanto a los mismos indios, más tarde, en las guerras por la independencia, en algunos lugares aislados del oriente de Cuba, inicialmente tomaron partido por el gobierno español y luego por el de los patriotas (Torres 2006: 106-107).

\section{Segunda mitad del siglo XIX (Antropología naciente y aborígenes)}

La Antropología y Etnología, generadas en Europa desde la segunda mitad del siglo XVIII a partir del conocimiento de pueblos no europeos, se formalizaron en el siguiente siglo. Algunos de sus miembros visitaron Las Antillas, incluida Cuba. El etnólogo alemán Adolf Bastian estuvo estudiando varias familias de indios en los años 70 del siglo XIX en el oriente de la isla, pero esta labor no se reflejó en sus publicaciones (Rangel 2012: 157-158).

En 1877 en Cuba fue creada la Sociedad Antropológica, como correspondiente de la Sociedad Antropológica Española de Madrid (Rivero de la Calle 1966: VII-VIII), y la mayoría de los socios fueron médicos. Tenía cuatro secciones, una de las cuales al cabo de algún tiempo fue la de Etnología (Sociedad Antropológica 1966). Funcionó hasta 1895, y en sus sesiones se discutieron diferentes cuestiones, mayormente sobre la población de origen africano. De vez en cuando se trataron algunos asuntos 
relacionados con los antiguos habitantes de Cuba, como las deformaciones craneales o las hachas de piedra, pero el autor de este artículo solo ha encontrado una única mención a los indios contemporáneos. En una de las seciones de 1880 se dijo que "según las noticias recogidas por algunos durante la insurrección, todavía existen restos de aquella"5 (Anales 1880: 401). Antonio Bachiller y Morales, miembro de la Sociedad, publicó el libro Cuba Primitiva, Origen, lenguas, tradiciones e historia de los indios de las Antillas mayores y las Lucayas. Según el autor, su objetivo fue "la conservación de todos los recuerdos, antigüedades y las voces de los que poblaron la grande Antilla" (Bachiller 1883: 7). No mencionó a los indios actuales del oriente de Cuba.

\section{Primera mitad del siglo $\mathrm{XX}$ (el creciente interés por el pasado aborigen)}

En 1899 las autoridades norteamericanas de ocupación organizaron un censo de población en Cuba. Se reconocía la presencia en la isla de los indios de Yucatán, y sobre los de Cuba se dijo que durante la recogida de los datos para el censo no se hallaron sus vestigios, y que no los había (Report 1900: 67). La intervención de Estados Unidos en las Antillas favoreció el acceso de investigadores norteamericanos a esta región, incluida Cuba. Pocos años después del censo citado el etnólogo Stewart Culin mencionó en un artículo a los indios que él había visto en varios lugares del oriente de Cuba (en Rivero de la Calle 1973: 153-154). Asimismo, algunos arqueólogos también se refirieron a ellos (Harrington 1921, vol. II). A la misma época corresponde el inicio de la enseñanza de la Antropología en Cuba. Por una orden militar del Gobierno Interventor Americano fue creada la Cátedra de Antropología y Ejercicios Antropométricos para los estudiantes del Derecho. La enseñanza de Antropología condicionó la creación de un laboratorio y un museo, que se denominó Museo Antropológico Montané (Rivero de la Calle1966: X).

En el país se despertó el interés por su pasado aborigen (Ortiz 1922) y aparecieron obras sobre las aportaciones de los aborígenes a la cultura de la población cubana. Azcárate Rosel dedicó todo un capítulo, "La infuencia de los indios de Cuba en el medio cubano cultural", en su libro (Azcárate 1937). Se publicaron trabajos sobre la historia de los aborígenes cubanos (Pichardo 1945; Morales 1946, 1951), en los que se profundizaba con las investigaciones arqueológicas. En agosto de 1937 fue creada una institución estatal, la Comisión Nacional de Arqueología, que editaba su Revista de Arqueología. En 1941 esta Comisión fue renombrada como Junta Nacional de Arqueología y, al año siguiente, restructurada en Junta Nacional de Arqueología y Etnología (Reorganización 1946). En los primeros números de la citada revista no hay nada sobre los indios contemporáneos de Cuba. Más todavía, cuando en 1940 en Pátzcuaro, México, se convocó el Primer Congreso Indigenista Interamericano, en la ponencia "Indios de Cuba" enviada para el evento, su autor afirmó literalmente "la extinción total de la raza aborigen en Cuba, pudiendo subsistir cuando más y en mestizaje, descendientes de los primeros pobladores" (Morales 1942: 27).

5 Por "aquella" se refiere a la raza siboney de Cuba. La cita textual es como sigue: "El Sr. Orus advierte que tampoco se ha tenido en cuenta que pudiera tratarse de un mestizo de la raza siboney de Cuba y de otra de las que pueblan la Isla, pues según las noticias recogidas por algunos durante la insurrección, todavía existen restos de aquella" (Anales 1880: 401) 
Precisamente es en el decenio de 1940 cuando el joven geógrafo cubano Antonio Núñez Jiménez empezó a publicar artículos sobre los indios que él había visto en sus viajes por Oriente. Como el antropólogo cubano Manuel Rivero de la Calle dijo de él: "En una época de escepticismo [...] supo mantener vivo el recuerdo de los descendientes de nuestros aborígenes y señalar, en repetidas ocaciones, la presencia de los mismos en apartadas regiones de dicha provincia oriental" (Rivero de la Calle 1978: 153). Pero Fernando Ortiz, una persona de gran prestigio en los círculos intelectuales de Cuba, opinaba que los indios del Oriente de Cuba fueron descendientes de aborígenes traidos a Cuba de otras tierras, principalmente de Yucatán. El título de una publicación en la revista Bohemia, basada en una entrevista con Fernando Ortiz en 1948 fue muy significativo: "Mentiras y ficciones en la historia de los indios cubanos" (Rivero de la Calle 1973: 156; 1978: 153).

En 1952 el genetista norteamericano Reginald R. Gates visitó varios lugares del oriente cubano. A diferencia de quienes antes solamente mencionaban a los indios de allá (viajeros, arqueólogos, geógrafos y otros), Gates los estudió y publicó los resultados de su investigación, concluyendo que no era cierto que "los indios de Cuba fueron exterminados alrededor del año 1600 D.C.", y que los indios vistos por Culin eran descendientes de los indios de Cuba ("taínos", según su calificación") y no de yucatecos (Rivero de la Calle 1973: 157-160).

\section{Después de 1959 (negados por el estado e ignorados por los etnólogos cubanos)}

Después de la revolución de 1959 el nuevo gobierno creó el Instituto Nacional de Etnología y Folklore, adscrito al Consejo Nacional de Cultura, por la Ley No. 994 del Consejo de Ministros del 19 de diciembre de 1961. En uno de los "por cuanto" se decía: "La población cubana, como consecuencia del proceso de colonización, se formó de multiples aportaciones étnicas venidas en distintos momentos de nuestra historia de puntos geográficos diferentes..." (Creación 1961:34-35). No se mencionó a la población aborigen, como si, incluso, no hubiera existido antes de la colonización de la isla por los europeos. Más tarde el Instituto formó parte de la Academia de Ciencias recien instituida.

En 1964 se efectuó la primera salida de los investigadores cubanos para estudiar a los indios del oriente del país. En la expedición a Yateras participaron los representantes de la Academia de Ciencias de Cuba (arqueólogo Rodolfo Payares) y de la Universidad de la Habana (antropólogo físico Manuel Rivero de la Calle). Formaron parte del grupo los antropólogos V. Guinsburg de la URSS, M. Pospišil de Checoeslovaquia y el etnólogo y escritor Miloslav Stingl del mismo país (Rivero de la Calle 1978: 160). Como se ve, en este acontecimiento importante no estaba presente la etnología cubana.

Según Rivero de la Calle, habían quedado descendientes de los aborígenes cubanos en varios lugares de la provincia del Oriente; la mayor parte se hallaba en el municipio Yateras (Rivero de la Calle 1973: 151-152). Este autor subrayó que en Yateras la expedición no encontró a los descendientes de los yucatecos, aunque en Patana Abajo, según comunicación personal de Calixta Guiteras, se identificaron

Los investigadores dieron a la población precolombina arauacohablante de las Antillas el nombre "tainos", el cual fue extendido a sus descendientes del tiempo de la Conquista y la Colonia. 
algunos mitos de origen mexicano (Rivero de la Calle 1973: 160). Calixta Guiteras residió -exiliada- en México durante varios años y estudió a varios pueblos aborígenes de aquel país. En 1961 regresó a Cuba, fue vicedirectora del Instituto de Etnología y Folklore. A principos de 1965 viajó al oriente de Cuba con otros miembros del Instituto y la etnóloga soviética Julia P. Averkieva, visitando algunos lugares con pobladores indios, pero desgraciadamente ninguno de los participantes dejó publicación alguna sobre este viaje.

Desde entonces, ni un solo miembro del Instituto de Etnología volvió a estudiar a los indios del oriente, salvo acompañando por un corto tiempo a algún investigador extranjero. Mientras, antropólogos físicos cubanos prosiguieron sus estudios en Yateras (Rivero de la Calle 1978: 160-161). En una revista cubana de amplia difusión, Revolución y Cultura, Rivero de la Calle, a la pregunta “¿Quedan indios en Cuba?”, respondió: "sólo nos quedan hoy grupos muy mezclados" en el municipio de Yateras, en el valle de Caujerí, en la zona de La Patana, en los alrededores de Baracoa y en algunas partes de la Sierra Maestra (Mosquera 1976-1977: 52).

Muy representativa es la opinón de Rivero de la Calle quien, al hablar de las discusiones sobre si existían en el país indios o sus descendientes, mencionó a historiadores, geógrafos y sociólogos (Rivero de la Calle 1978: 152) y, como buen conocedor del asunto, no habló de los etnólogos. A pesar de los muy informativos trabajos de Rivero de la Calle sobre los indios de Cuba, ningún miembro del Departamento de Etnología del Centro de Arqueología y Etnología de Academia de Ciencias dedicó sus estudios a ellos, aunque en el departamento hubo algun tiempo un grupo de investigadores dedicados al análisis de los movimientos sociales de los aborígenes del continente.

Después de la crisis de los años 90, condicionada por el derrumbe del bloque de paises socialistas con los que Cuba tenía relaciones muy estrechas de varios géneros, la comprensión de la cultura y la sociedad cubanas se perfilaba, cada vez más, bajo el concepto de la Antropología Sociocultural. Este fenómeno se percibe con más claridad en los programas universitarios de varias especialidades (Galván 2018). La vuelta del enfoque general no se reflejó nada en los estudios de los indios cubanos. Seguían publicandose trabajos sobre aborígenes, pero de los del pasado. Así, el libro

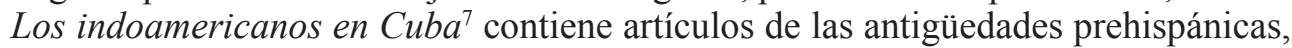
del período colonial, de los análisis serológicos, pero ninguno sobre los indios actuales del Oriente (Pérez Cruz 2014). En 2018 se publicó en Santo Domingo el libro De la desaparición a la permanencia: indígenas e indios en la reinvención del Caribe, que contiene un artículo sobre los descendientes actuales de los aborígenes de Cuba, escrito por José Barreiro y Alejandro Hartmann (Valcárcel y Ulloa 2018).

\section{Revitalización "taína" e indios cubanos}

Durante los últimos decenios los indios de Cuba quedaron envueltos en los procesos globales de la revitalización étnica que en las Antillas tomaron la forma del "tainismo”. En los años 70 los migrantes de Puerto Rico en Estados Unidos animados por los movimientos aborígenes de este país, fundaron "Taino Tribal Council" que en 1993 fue reformado como "Taino Inter-Tribal Council Inc." Los activistas de ese

Estoy muy agradecido al Dr. Jesús Guanche por sus muchos esfuerzos para que el libro llegara a mis manos. 
movimiento crean espacios en Internet donde publican materiales sobre la historia y la cultura de los aborígenes de las Antillas, así como sobre la vida de los "taínos" actuales. Hacen exposiciones sobre las antigüedades antillanas y del "arte contemporáneo taino", según su terminología. Están convencidos, y convencen a otros, que los aborígenes de las Antillas no desaparecieron totalmente como se creía, según ellos, hasta hace poco, y que los descendientes de antiguos pobladores pueden (o deben) ser llamados "taínos". El movimiento encontró el apoyo de algunos investigadores, entre los cuales se puede mencionar a José Barreiro, un cubano residente en Estados Unidos que tiene trabajos de varios géneros sobre "tainos" cubanos.

En 1989 en Estados Unidos fue aprobada una ley según la cual los museos federales tendrían que inventariar los restos humanos que conservaban para devolvérselos al grupo indígena que los reclamara. Los líderes del movimiento taíno lograron obtener el permiso correspondiente para Cuba, y en Caridad de los Indios (municipio Yateras, Oriente) fueron reinhumados los fragmentos de huesos llevados de allí al Instituto Smithsonian por el arqueólogo Mark R. Harrington. En el acto participaron los pobladores locales junto con los representantes del dicho Instituto y de tres pueblos aborígenes de Norteamerica (Eaton 2003).

\section{Conclusiones}

Los aborígenes de Cuba, tras la conquista de principios del siglo XVI, perdieron sus denominaciones propias, convirtiendose todos en "indios". Perdieron también sus lenguas nativas y fueron convertidos al catolicismo. Esos procesos tenían lugar al mismo tiempo que la dramática disminución demográfica y el intenso mestizaje con los pobladores de otras procedencias. La identidad india se ha mantenido en algunos grupos de lugares apartados del extremo oriente de la isla a traves de la memoria (escrita $u$ oral) y de algunos rasgos físicos.

Cuando a fines del siglo XIX se perfiló la Antropología en Cuba, la atención de los cubanos fue dirigida mayormente al estudio de la población de origen africano, un grupo grande y activo de la sociedad. Tal preferencia se desarrolló en todo el siglo XX sobre todo por los trabajos de Fernando Ortiz, con centenares de páginas sobre folklore, bailes, instrumentos musicales, creencias y muchos otros aspectos. Además, el sabio cubano, que tenía enorme prestigio científico, negaba la supervivencia indígena en Cuba (Rivero de la Calle 1978: 153; véase también Quintero 2017).

Otra causa posible de la desatención de los etnólogos de Cuba a los indios cubanos es la inestabilidad institucional de la etnología en el país. Se organizó formalmente afiliándose a la Arqueología como una hermana menor de esta. Desde fines del 1961 hasta 1969 formaba parte del Instituto Nacional de Etnología y Folklore (primero dentro del Consejo Nacional de Cultura y después de la Academia de Ciencias de Cuba). De 1970 a 1973 la Etnología existió autonomamente dentro del Instituto omónimo (Álvarez y Álvarez 2002). Fue precisamente cuando en el Instituto funcionó la Escuela de Etnología dirigida por Calixta Guiteras (1970-1973). En 1973 fue creado el Instituto de Ciencias Sociales de la Academia de Ciencias de Cuba, y la Etnología pasó a este instituto con el rango de departamento. En marzo de 1986 fue sustituido por el Instituto de Ciencias Históricas (organización presupuestaria desde abril de 1987) y, en mayo de 1988, cambió su nombre por el de Centro de Arqueología y Etnología. A fines del año 1990 se convirtió en el Centro de 
Antropología con departamentos de Arqueología y Etnología. Desde junio del 2006 es el Instituto Cubano de Antropología (Instituto Cubano de Antropología s.f.) con los mismos departamentos. Por otro lado, la carrera de etnólogo nunca existió en la educacion superior, aunque en varios centros (educacionales o de investigación) se daban las asignaturas correspondientes para supuestos etnólogos o para otro género de especialidades.

Hay un factor probable más que debe tomarse en cuenta para explicar la falta de atención por parte de los etnólogos cubanos hacia los indios del país: el comportamiento de los mismos. Aislados y separados unos de otros -grupos e individuos-, no levantaron su voz durante más de siglo y medio, ni tenían ninguna organización cultural que los animara y uniera. Hasta el punto que Rivero de la Calle pronosticó su rapida desaparición por la fuerza del desarrollo económico acelerado de la región donde habitaban (Rivero de la Calle 1978: 175). Algo ha cambiado con la actividad del movimiento tainista como he mostrado.

El aspecto más interesante de las posibles investigaciones de los etnólogos sobre los descendientes de los aborígenes cubanos sería pormenorizar las circunstancias de la conservación de la identidad india, estableciendo sus correlaciones con los procesos económicos, sociales y culturales en los cuales los indios se vieron involucrados. Otro aspecto complementario sería definir el funcionamiento de esta identidad en la actualidad. Ello permitiría la comparación del proceso en Cuba con otros semejantes en diferentes partes del continente y así ayudar a su compresión.

\section{Referencias}

\subsection{Referencias documentales}

ANC (Archivo Nacional de Cuba)

—. Padrón general de habitantes del pueblo de Jiguaní. 1774. Miscelánea de Expedientes, Legajo 4076 /Aj.

—. Padrón general de los habitantes de la jurisdicción de Jiguaní. 1774 Miscelánea de Expedientes, Legajo 4076 /Al.

—. Padrón general de los habitantes del pueblo de San Luis del Caney. 1775. Gobierno General, Legajo 489, No. 25122.

—. Padrón general de los habitadores del partido del Caney. 1775. Gobierno General, Legajo 489, No. 25123.

\subsection{Referencias bibliográficas}

Álvarez Sandoval, Orieta y Alfredo A. Álvarez Hernández. 2002. "Las Ciencias sociales en la Academia de Ciencias de Cuba (1962-1981)". Tiempos de América 9: 59-78. https:// raco.cat/index.php/TiemposAmerica/article/view/105141.

Anales. 1880. Anales de la Real Academia de Ciencias Médicas, Físicas y Naturales de La Habana. Revista Cientifica, Tomo XVII.

Arrate, José Martín Félix de. 1964. Llave del Nuevo Mundo. Antemural de las Indias Occidentales. La Habana descripta: noticias de su fundación, aumentos y estados. La Habana: Comisión Nacional de la UNESCO.

Azcárate Rosell, Rafael. 1937. Historia de los indios de Cuba. La Habana: Editorial Trópico. 
Bachiller y Morales, Antonio. 1883. Cuba Primitiva. Origen, lenguas, tradiciones e historia de los indios de las Antillas mayores y las Lucayas. $2^{\mathrm{a}}$ ed. Habana: Librería de Miguel de Villa. https://ufdcimages.uflib.ufl.edu/AA/00/05/93/31/00001/cubaprimitivaori00bach.pdf.

CDI-2. 1891. Colección de Documentos Inéditos Relativos al Descubrimiento, Conquista y Organización de las Antiguas Posesiones Españolas de Ultramar. $2^{a}$ Serie. Tomo 6, III, De La Isla De Cuba. Madrid: Establecimiento Tipográfico "Sucesores de Rivadeneyra".

Creación. 1961. "Creación del Instituto de Etnología y Folklore”. Actas del Folklore 10-12: 33-35.

Documentos. 1973. Documentos para la historia de Cuba. Tomo 1. La Habana: Editorial de Ciencias Sociales.

Eaton, Tracey. 2003. “An Indigenous Revival in Cuba?”. The Dallas Morning News. Posted July 12. https://traceyeaton.com/index.php/an-indigenous-revival-in-cuba/.

Galván Tudela, José Alberto. 2018. "Hacia una Historia de la Antropología Sociocultural en Cuba". Batey: una revista cubana de Antropología Social 11 (2) : 4-33.

Harrington, Mark R. 1921. Cuba before Columbus. Vols. 1 y 2. Nueva York: Museum of the American Indian, Heye Foundation.

Instituto Cubano de Antropología. https://www.ecured.cu/Instituto_Cubano_de_ Antropolog\%C3\%ADa\#Antecedentes.

Konetzke, Richard. 1953. Colección de documentos para la historia de la formación social de Hispanoamérica 1493-1810. Volumen I (1493-1592). Madrid: Consejo Superior de Investigaciones Científicas.

Licea Bello, Gerardo. 2012. "En torno a la historia temprana de Jiguaní. Algunas precisiones necesarias". Contribuciones a las Ciencias Sociales 16. http://www.eumed.net/rev/ cccss/20/glb.html.

Marrero, Leví. 1972-1992. Cuba: economía y sociedad. Tomos 1-15. San Juan, Madrid: Editorial San Juan, Playor.

Morales Coello, Julio. 1942. "Las ciencias antropológicas en Cuba. 1925-1940”. Revista de Arqueología 6: 7-29.

Morales Patiño, Osvaldo. 1946. La rebeldía de los indocubanos. La Habana: Grupo Guamá.

-. 1951. "Los indígenas en los primeros municipios cubanos". Revista de Arqueología y Etnología 13-14: 368-387.

Morell de Santa Cruz, Pedro Agustin. 1985. La visita eclesiástica. La Habana: Editorial de Ciencias Sociales.

Mosquera, Gerardo. 1976-1977. “Ocho preguntas sobre la prehistoria cubana”. Revolución y Cultura 52-54: 44-57.

Ordenanzas. 1905. “Ordenanzas municipales de la Habana y de los demás pueblos de la isla de Cuba por el oidor D. Alonso de Cáceres. Enero 14 de 1574", en Introducción a la historia de las instituciones locales de Cuba, Tomo $2^{\circ}$, Francisco Carrera y Justiz, pp. 255-300. Habana: Librería e imprenta "La Moderna Poesía".

Ortiz Fernández, Fernando. 1922. Historia de la arqueología indocubana. La Habana: Imprenta El Siglo XX.

Papeles. 1931. Papeles existentes en el Archivo General de Indias relativos a Cuba y muy particularmente a La Habana. Tomos I y II. La Habana: Academia de la Historia de Cuba.

Pérez Cruz, Felipe de Jesús, coord. 2014. Los indoamericanos en Cuba. Estudios abiertos al presente. La Habana: Editorial de Ciencias Sociales.

Pérez de la Riva, Juan. 1972. "Desaparición de la población indígena de Cuba". Revista de la Universidad de La Habana 196-197: 61-84. 
—. 1977. "Presentación de un censo ignorado: El Padrón General de 1778". Revista de la Biblioteca Nacional José Martí 3: 5-16.

Pichardo Moya, Felipe 1945. Los indios de Cuba en sus tiempos históricos. La Habana: Imprenta El Siglo XX.

Quintero Angulo, Gretel. 2017. "Sobre la exclusión de lo aborigen en la construcción de la nacionalidad cubana". La Jiribilla. Revista de Cultura Cubana XVI: 21 de Octubre-3 de Noviembre. http://www.lajiribilla.cu/articulo/sobre-la-exclusion-de-lo-aborigen-en-laconstruccion-de-la-nacionalidad-cubana.

Rangel Rivero, Armando. 2012. Antropología en Cuba. Origen y desarrollo. Madrid: Fundación Fernando Ortiz.

Recopilación. 1841. Recopilación de leyes de los reinos de las Indias. Tomo 2. Madrid: Boix, editor.

Reorganización. 1946. "Reorganización de la Junta Nacional de Arqueología con el caracter de Junta Nacional de Arqueología y Etnología". Revista de Arqueología y Etnología 2: 30-38.

Report. 1900. Report on the Census of Cuba 1899. Washington D.C.: Government Printing Office.

Reyes Cardero, Juan Manuel. 2009. “La inserción del aborigen en la sociedad colonial santiaguera: el caso del pueblo indio de San Luis de Los Caneyes". Ciencia en su PC 1: 3-16. http://www.redalyc.org/articulo.oa?id=181321570001.

Ribera, Nicolás Joseph de. 1975. Descripción de la isla de Cuba. Con algunas consideraciones sobre su población y comercios. La Habana: Editorial de Ciencias Sociales.

Rivero de la Calle, Manuel. 1966. "Prólogo", en Sociedad Antropológica de la isla de Cuba, Actas, pp. VII-XIII. La Habana: Comisión Nacional Cubana de la UNESCO.

—. 1973. "Los indios cubanos de Yateras". Santiago 10: 151-174.

—. 1978. "Supervivencia de descendientes indoamericanos en la zona de Yateras, Oriente", en Cuba Arqueológica I, pp. 149-176. Santiago de Cuba: Editorial Oriente.

Santamaría García, Antonio y Sigfrido Vázquez. 2013. "Indios foráneos en Cuba a principios del siglo XIX: historia de un suceso en el contexto de la movilidad poblacional y la geoestrategia del imperio español”. Colonial Latin American Historical Review 18 (1): 1-34. https://digitalrepository.unm.edu/clahr/vol18/iss1/1/.

Sociedad Antropológica de la Isla de Cuba. 1966. Actas. La Habana: Comisión Nacional Cubana de la UNESCO.

Torres Etayo, Daniel Alejandro. 2006. Taínos: mitos y realidades de un pueblo sin rostro. México: Editorial Asesor Pedagógico. Documento descargado de Cuba Arqueológica www.cubaarqueologica.org.

Valcárcel Rojas, Roberto. 2015. "Una presencia necesaria. Indios en la Cuba colonial”. Boletín del Museo del Hombre Dominicano 46: 179-194. https:/www.academia.edu/27289104/ Indios en Cuba Una presencia necesaria .

Valcárcel Rojas, Roberto y Jorge Ullōa Hung. 2018. "Introducción. La desaparición del indígena y la permanencia del indio", en De la desaparición a la permanencia: indígenas e indios en la reinvención del Caribe, Roberto Valcárcel Rojas y Jorge Ulloa Hung, eds., pp. 5-39. Santo Domingo: Fundación García Arevalo. https://www.academia.edu/37887742/ De_la_desaparici\%C3\%B3n_a_la_permanencia_Ind\%C3\%ADgenas_e_indios_en_la_ reinvenci\%C3\%B3n_del_Caribe.

Zerquera y Fernández de Lara, Carlos J. 1977. "La villa india de Trinidad en el siglo XVI”. Revista de la Biblioteca Nacional “José Marti”" XIX (2): 71-94. https://ufdc.ufl.edu/ AA00068207/00085. 